\title{
Oil Extraction from Butter Fruit (Dacryodes Edulis) Seeds and its Optimization via Response Surface and Artificial Neural Network
}

\author{
T. F. Adepoju ${ }^{1 *}$, I. O. Esu ${ }^{1}$, O. A. Olu-Arotiowa ${ }^{2}$, E. Blessed ${ }^{1}$ \\ ${ }^{1}$ Chemical/Petrochemical Engineering, Department, Akwa-Ibom, State University, Ikot Akpaden, Nigeria. \\ ${ }^{2}$ Chemical Engineering, Ladoke Akintola University of Technology, Ogbomosho, Nigeria.
}

\begin{abstract}
In this study, oil was extracted from butter fruit (Dacrydes edulis). To model and optimize the process conditions of oil extraction, Response Surface Methodology (RSM) and Artificial Neural Network (ANN) were used. Physicochemical analysis of the oil was carried out in order to determine the suitable of oil for industrial applications. Dacryodes edulis seeds were collected from Ikot Abasi Village in Eket Local Government of Akwa Ibom State, Nigeria. The seed was washed with clean water to remove dirt, and open with a sharp stainless knife to remove the seed from the pulp. The seeds were cut into small pieces and sundried for 5 days and were grinded into powder. Oil extraction from the powder seed was carried out using Sohxlet extraction method. The experiment was designed using Box-Behnken Design approach on three levels, three factors which generated 17 experimental runs. Independent factors considered were extraction time $\left(\mathrm{X}_{1}\right)$, solvent volume $\left(\mathrm{X}_{2}\right)$ and sample weight $\left(\mathrm{X}_{3}\right)$. The accuracy of the regression model obtained from the optimization software was determined using the co-efficient of determination $\left(\mathrm{R}^{2}\right)$. Results showed the highest oil yield of $17.878 \%(\mathrm{w} / \mathrm{w})$ was obtained at solvent volume of 200 $\mathrm{ml}$, sample weight of $50 \mathrm{~g}$ and extraction time of $55 \mathrm{~min}$, respectively. However, response surface methodology predicted an oil yield of $17.826 \%(\mathrm{w} / \mathrm{w})$, while the artificial neural network predicted $17.875 \%(\mathrm{w} / \mathrm{w})$ at the same variables condition. The predicted values were validated in triplicate, and an average of $17.46 \%(\mathrm{w} / \mathrm{w})$ and $17.72 \%$ (w/w) were obtained for RSM and ANN, respectively. The predicted values obtained were well within the range predicted. The coefficient of determination, which determines the model accuracy, was obtained to be 0.8454 for RSM and 0.8712 for ANN. Physicochemical analysis of the oil showed the oil is highly unsaturated with high saponification value and high iodine value. The study concluded that Dacryodes edulis seeds are found to be rich in oil and the oil can be applicable in industries as raw materials for products formation.
\end{abstract}

KEYWORDS: Dacryodes edulis seeds, response surface, artificial neural network, optimization, extraction, physicochemical properties.

[Received April 16, 2018; Revised September 06, 2018; Accepted September 19, 2018]

Print ISSN: 0189-9546 | Online ISSN: 2437-2110

\section{INTRODUCTION}

The use of oil in Industries for production of cosmetic, biofuel, bio lubricant and other products has become greatly increase, which has necessitated the needs to search for alternative source through biomass (Agricultural oilseeds). To meet up with the needs of the incessant increase in the demand for oil by both domestic and industries have resulted in search for using underutilized seeds as sources of oil to supplement the already current traditional sources of oil (Ugbogu et al., 2014). In some nation, specifically Nigeria, different oil crops exist from the largely used and highlyutilized to under-utilized seed oils that have not been investigated for their potential uses.

Dacryodes edulis, an annual fruit known as African plum or African pear or Safou seed is one of the under-utilized seed oil. It is an indigenous fruit tree in the humid low lands and plateau regions of West, Central African and Gulf of Guinea countries. Usually, the trees are grown around homesteads and flowering always takes place from January to April, with fruiting season between May and October (Nwosuagwu et al.,
2009). The pear is locally called 'Ube' among the Igbos in South eastern part of Nigeria belongs to the family of Burseraceae and genus Dacryodes (Ogunsuyi, 2015). It has the qualities of butter apart from the pulp outlook which contains $48 \%$ oil; the overall plantation can produce $7-8$ tonnes of oil per hectare.

Generally, the extraction of oil from the seeds can be achieved via various methods such as mechanical, (Joglekar and May, 1987; Haidar and Pakshirajah, 2007; Schinas et al., 2009) pressurized solvent extraction (Mcginely, 1991), soxhlet extraction (Meher et al., 2006), ultrasonic extraction (Ramos et al., 2009; Rodríguez et al., 2012), Aqueous Enzymatic Oil Extraction (AEOE) (Perez-Serradilla et al., 2002; Pan et al., 2002), stirring and shaking extraction (Kim et al., 2004) to mention but few. These methods have been reported used for extraction of vegetable oils and other plant essential components, each with intrinsic advantages and shortcomings (Umer et al., 2011). Mechanical pressing is the oldest and easiest method used widely, but, the oil produced always with low value. Meanwhile, (Betiku and Adepoju, 
2013) reported the use of supercritical CO2 extraction; the oil yield obtained was higher than what was obtained from using solvent extraction and of high purity, but the high operating and investment costs make this method not suitable to be used. Solvent extraction has various advantages including high yield, less turbidity, environmentally friendly and cost effective (Adepoju et al., 2013; Betiku et al.,2012), which was why solvent extraction of oil from Jatropha curcus was carried out by (Kian et al., 2011), while (Umer et al., 2011) studied the solvent extraction of oil from Moringa oleifera. Betiku et al. (2012) extracted oil from sorrel seed using solvent extraction while solvent extraction of oil from Chrysophyllum albidium oilseeds and its quality characterization was carried out by (Adepoju et al., 2013). In another study, Betiku et al. (2012) worked on solvent extraction of oil from Beniseed (Sesamum indicum) oilseeds.

This work therefore employed the possibility of using Dacryodes edulis seed for oil production. For modelling and optimization, response surface methodology (RSM) and artificial neural network (ANN) were employed so as to generate the number of experimental runs, determine the predicted yields, compare the error values, and analyse the various variable factors responsible for optimum production of oil so as to increase the process efficiency. Lastly, the properties of oil were evaluated with a view to determining its suitability as edible or non-edible oil.

\section{MATERIALS AND METHODS}

\section{A. Materials}

The Dacryodes edulis seeds used in this work was collected from Ikot Abasi Village in Eket Local Government of Akwa Ibom State, Nigeria. The seed was washed with clean water to remove dirt, and open with a sharp stainless knife to remove the seed from the pulp. The seeds were cut into small pieces and sundried for 5 days. Finally, the cleaned seeds were grinded into powder with a Corona grinder. All the chemicals used in this study are of analytical grades.

\section{B. Methods}

\section{1) Experimental design}

To optimize the oil extraction from Dacryodes edulis seeds powder, three level-three factors were considered. BoxBehnken Design (BBD ${ }_{\text {RSM }}$ ) was employed which generated 17 experimental runs used to study the effects of selected factors on oil yield. Table 1 showed the selected factors which are solvent volume $\left(\mathrm{X}_{1}\right)$, sample weight $\left(\mathrm{X}_{2}\right)$ and the extraction time $\left(\mathrm{X}_{3}\right)$ and their levels. These factors were also used for ANN Modeling and optimization. For the coefficient of the quadratic model of the response fitting, multiple regressions model was adopted using design expert software 10 version 15.5 (Stat Inc., Tulsa, OK, USA) and Neural Power_21356. Regression analysis and test of significance are the computationally intensive process that is best carried out via statistical software; hence the quality of the fitted model was evaluated using test of significance and regression analysis of variance (ANOVA) via Eq. 1. To compare the results of the model chosen and validate the coefficient of determination of the experimental result, artificial neural network (ANN) was incorporated.

$R_{F}=\tau_{0}+\sum_{i=1}^{k} \tau_{i} X_{i}+\sum_{i=1}^{k} \tau_{i i} X_{i}^{2}+\sum_{i<j}^{k} \tau_{i j} X_{i} X_{j}+e$

where, $\mathrm{R}_{\mathrm{F}}$ is the response (oil yield), $\tau_{0}$ is the intercept term, $\tau_{i}, \tau_{i i}, \tau_{i j}$ are the coefficient terms for linear $\left(X_{i}\right)$, quadratic $\left(X_{i}^{2}\right)$ and interaction $\left(X_{i} X_{j}\right), X_{i}$ is the selected factors, $i=1,2$, 3 .

Table 1: Factors and their Levels for Box - Behnken Design.

\begin{tabular}{lllll}
\hline Variable & Symbol & \multicolumn{3}{c}{ Coded factor levels } \\
\cline { 3 - 5 } & & $\mathbf{- 1}$ & $\mathbf{0}$ & $\mathbf{+ 1}$ \\
\hline SV $(\mathrm{ml})$ & $\mathrm{X}_{1}$ & 180 & 200 & 220 \\
SW $(\mathrm{g})$ & $\mathrm{X}_{2}$ & 40 & 50 & 60 \\
ET (min) & $\mathrm{X}_{3}$ & 50 & 55 & 60
\end{tabular}

$\mathrm{SV}=$ Solvent volume, $\mathrm{SW}=$ Sample weight, $\mathrm{ET}=$ Extraction time

\section{2) Description of oil extraction procedure}

Based on the experimental design by Box Behken Design, seventeen experimental runs were generated and were carried out. Soxhlet extractor was used for the extraction process; the powdered sample was weighed and placed in the extractor through the muslin cloth. N-hexane was used as organic solvent for extraction. Three level three factors were considered, the excess n-hexane was recovered using rotary evaporator, and the yield of the oil was obtained using Eq. (2).

$$
\text { Oil yield }(\%)=\frac{\text { weight of oil }}{\text { weight Dacryodes edulis powder used }}
$$

3) Physicochemical analysis of the extracted Dacryodes edulis seed oil

The properties of the oil were evaluated using standard of AOAC (1997), official methods of analysis and Wij's iodine method as described below:

$0.52 \mathrm{~g}$ of oil sample was dissolved in $10 \mathrm{ml}$ of cyclohexane. $20 \mathrm{ml}$ of Wij's solution was added, the stopper flask was allowed to stand for $30 \mathrm{~min}$ in the dark at room temperature, and $20 \mathrm{ml}$ of $10 \%$ potassium iodide solution was added. The resulting mixture was then titrated with $0.1 \mathrm{M}$ $\mathrm{Na}_{2} \mathrm{~S}_{2} \mathrm{O}_{3}$ using starch as indicator. Iodine value was calculated using equation 3 .

$$
\text { Iodine Value }=\frac{\left[\rho_{o}-\rho\right] \times M X 12.69}{0.26}
$$

where $\mathrm{M}=$ concentration of sodium thiosulphate used; $\rho_{o}=$ volume of sodium thiosulphate used as blank; $\rho=$ volume of sodium thiosulphate used for determination.

\section{4) Variable interactive effects}

To study the effects of independent variables on oil yield, three factors were taking into consideration (Table 1). The interactive effects of the variables on the oil yield were considered by allowing for the linear $\left(X_{1}, X_{2}, X_{3}\right)$, the interaction $\left(\mathrm{X}_{1} \mathrm{X}_{2}, \mathrm{X}_{1} \mathrm{X}_{3}, \mathrm{X}_{2} \mathrm{X}_{3}\right)$ and the quadratic $\left(\mathrm{X}_{1}^{2}, \mathrm{X}_{2}^{2}\right.$, 
$\mathrm{X}_{3}{ }^{2}$ ) on the response. The variable interactive effects also lead to the formation of regression equation (Eq. 1) and explained vividly how the contour and three-dimensional plots are obtained.

\section{Optimization of Dacryodes edulis Seed Oil Extraction}

The important part of any regression analysis is to determine whether or not the standard assumptions of the simple linear regression model are satisfied. The relationship between the response variable (oil yield) and selected variables $\left(\mathrm{X}_{1} ; \mathrm{X}_{2} ; \mathrm{X}_{3}\right)$ are assumed to be in form of linear, interactions and quadratic (Eq. 1). To check the model accuracy and model estimation capabilities, the coefficient of determination $\left(\mathrm{R}^{2}\right)$ was determined by estimating these parameters using Eqns. (4). Their values were used together to juxtapose the Box Behnken design and genetic algorithm models by comparing the evaluated values for the models.

$$
R^{2}=1-\sum_{i=1}^{n} \frac{\left(\emptyset_{i, \text { cal }}-\emptyset_{i, \text { exp }}\right)^{2}}{\left(\emptyset_{\text {avg,exp }} \emptyset_{i, \text { exp }}\right)^{2}}
$$

where $\emptyset_{i, \exp }$ is the experimental value, $\emptyset_{i, c a l}$ is the calculated value and $\emptyset_{\text {avg,exp }}$ is the average experimental value.

\section{RESULTS AND DISCUSSION}

\section{Optimization of oil extraction}

Table 2 depicts the 17 experimental generated, the oil yield results obtained together with the predicted oil yield and the residual values. It was observed that the lowest yield obtained was $8.1188 \%(\mathrm{w} / \mathrm{w})$ and the predicted values for RSM and ANN couple with genetic algorithms were $8.0668 \%$ $(\mathrm{w} / \mathrm{w})$ and $8.5722 \%(\mathrm{w} / \mathrm{w})$, respectively. Meanwhile, the highest yield obtained was $17.8780 \%(\mathrm{w} / \mathrm{w})$, while the predicted values for RSM and ANN were $17.726 \%$ and $17.876 \%(\mathrm{w} / \mathrm{w})$, respectively. The predicted values were validated in triplicate, and an average of $17.46 \%(\mathrm{w} / \mathrm{w})$ and $17.72 \%(\mathrm{w} / \mathrm{w})$ were obtained for RSM and ANN, respectively.

Table 3 showed the results of test of significance for all coefficient of regression. The F-values of $\mathrm{X}_{1}, \mathrm{X}_{2}, \mathrm{X}_{1} \mathrm{X}_{2}$ and $\mathrm{X}_{1} \mathrm{X}_{3}$, implies the significant model terms. Values of "Prob > $F^{\prime \prime}$ less than 0.0500 indicate model terms are significant. Table 4 showed the results of the Analysis of Variance (ANOVA). The analysis of variance is important to test significance and suitability of the model and to determine whether the variation from the model is significant when compared to the variation due to residual error at $95 \%$ confidence level. The "Lack of Fit" compares the residual error to the pure error from simulated design points. The lack of fit F-value of 11.37 with p-value 0.199 implies insignificant lack of fit relative to pure error.

The mathematical expression of the relationship between oil yield and the variable factors is given by the model equation 4. All negative values have reduction impact on the yield while positive values have ability to increase the yield (Table 5).
$\mathrm{OY}(\%)=+12.48-1.01 \mathrm{X}_{1}+1.28 \mathrm{X}_{2}-1.44 \mathrm{X}_{3}-1.78 \mathrm{X}_{1} \mathrm{X}_{2}$ $-0.98 \mathrm{X}_{1} \mathrm{X}_{3}-1.00 \mathrm{X}_{2} \mathrm{X}_{3}-0.59 \mathrm{X}_{1}^{2}+0.095 \mathrm{X}_{2}^{2}-1.861 \mathrm{X}_{3}^{2}$

To test the fit of the model equation, the regression model was established using $\mathrm{R}^{2}$ as a measure of how much variability in the observed response values can be explained by the experimental factors and their interactions (Sudamalla et al., 2012). The $\mathrm{R}^{2}$ value is always between 0 and $100 \%$ (Haider and Pakshirajah, 2007; Schinas et al., 2009). However, to create a good-fit model, it was recommended that $\mathrm{R}^{2}$ should not be less than $80 \%$ (Joglekar and May 1987). The results in Table 4 indicated an $R^{2}$ value of $84.54 \%$ for RSM and $87.12 \%$ for ANN, which leaves only $15.46 \%$ and $12.87 \%$ of the variability, not explains by oil yield, this indicates that an unexplainable total variation could be caused by other factors, which were not included in the model. Figure 1 shows the relationship between the predicted plots (RSM and ANN) and the actual experimental oil yield.

A graphical drawing depicts a functional relation between two or three variables by means of a curve or surface containing only those points, whose coordinates satisfy

Table 2: Box-Behnken Experimental Design for Three Independent Factors.

\begin{tabular}{lllllllll}
\hline $\begin{array}{l}\text { Std. } \\
\text { run }\end{array}$ & $\mathbf{X}_{\mathbf{1}}$ & $\mathbf{X}_{\mathbf{2}}$ & $\mathbf{X}_{\mathbf{3}}$ & $\begin{array}{l}\text { Oil } \\
\text { yield }\end{array}$ & \multicolumn{2}{c}{ Predicted } & \multicolumn{2}{c}{ Residual } \\
& & & & $\begin{array}{l}\text { RSM } \\
\text { \%(w/w) }\end{array}$ & ANN & RSM & ANN \\
\hline 1 & 1 & 1 & 0 & 13.1102 & 13.0282 & 13.129 & 1.69 & 0.019236 \\
2 & 0 & 0 & 0 & 17.8780 & 17.826 & 17.875 & 6.47 & 0.0030479 \\
3 & 0 & 1 & 1 & 13.5602 & 13.5082 & 12.476 & 0.40 & 1.0838 \\
4 & 0 & -1 & 1 & 12.6760 & 12.624 & 12.476 & -0.55 & 0.19955 \\
5 & 1 & -1 & 0 & 9.6400 & 9.588 & 9.7187 & -1.77 & 0.078717 \\
6 & 0 & 1 & -1 & 8.8878 & 8.8358 & 8.9299 & -1.85 & 0.042103 \\
7 & -1 & 0 & -1 & 9.0790 & 9.027 & 9.0722 & -0.16 & 0.0067995 \\
8 & 0 & 0 & 0 & 12.1744 & 12.1224 & 12.476 & 0.55 & 0.30205 \\
9 & 0 & 0 & 0 & 9.9718 & 9.9198 & 9.958 & -2.25 & 0.013816 \\
10 & -1 & 0 & 1 & 11.4024 & 11.3504 & 12.476 & -8.34 & 1.074 \\
11 & 0 & 0 & 0 & 9.4003 & 9.3483 & 9.3893 & -1.69 & 0.011029 \\
12 & -1 & 1 & 0 & 12.5876 & 12.5356 & 12.476 & 2.25 & 0.11115 \\
13 & 1 & 0 & 1 & 8.1188 & 8.0668 & 8.5722 & -3.29 & 0.4534 \\
14 & 1 & 0 & -1 & 9.2843 & 9.2323 & 8.7767 & -0.40 & 0.50758 \\
15 & -1 & -1 & 0 & 14.1445 & 14.0925 & 14.151 & 1.85 & 0.0062827 \\
16 & 0 & -1 & 1 & 11.3265 & 11.2745 & 11.305 & 0.16 & 0.021387 \\
17 & 0 & 0 & -1 & 10.0145 & 9.9625 & 10.034 & -1.40 & 0.019628 \\
\hline
\end{tabular}

\begin{tabular}{|c|c|c|c|c|c|}
\hline Source & $\begin{array}{l}\text { Sum } \\
\text { squares }\end{array}$ & of df & $\begin{array}{l}\text { Mean } \\
\text { Square }\end{array}$ & $\begin{array}{l}\text { F- } \\
\text { value }\end{array}$ & p-value \\
\hline $\mathrm{X}_{1}$ & 18.23 & 1 & 18.23 & 12.45 & 0.01617 \\
\hline $\mathrm{X}_{2}$ & 13.10 & 1 & 13.10 & 13.89 & 0.0391 \\
\hline$X_{3}$ & 16.67 & 1 & 16.67 & 8.96 & 0.0613 \\
\hline $\mathrm{X}_{1} \mathrm{X}_{2}$ & 12.65 & 1 & 12.65 & 11.76 & 0.0437 \\
\hline$X_{1} X_{3}$ & 3.82 & 1 & 3.82 & 10.13 & 0.04600 \\
\hline $\mathrm{X}_{2} \mathrm{X}_{3}$ & 4.03 & 1 & 4.03 & 1.20 & 0.3101 \\
\hline $\mathrm{X}_{1}^{2}$ & 1.49 & 1 & 1.49 & 10.44 & 0.05277 \\
\hline $\mathrm{X}_{2}^{2}$ & 0.038 & 1 & 0.038 & 0.011 & 0.9186 \\
\hline $\mathrm{X}_{3}{ }^{2}$ & 14.63 & 1 & 14.63 & 4.35 & 0.0755 \\
\hline
\end{tabular}

Table 4: Analysis of variance (ANOVA) of regression equation.

\begin{tabular}{llllll}
\hline Source & $\begin{array}{l}\text { Sum of } \\
\text { squares }\end{array}$ & df & $\begin{array}{l}\text { Mean } \\
\text { Square }\end{array}$ & $\begin{array}{l}\text { F- } \\
\text { value }\end{array}$ & $\begin{array}{l}\text { p- } \\
\text { value }\end{array}$ \\
\hline Model & 175.16 & 9 & 19.46 & 12.48 & 0.0122 \\
Residual & 23.55 & 7 & 3.36 & & \\
Lack of fit & 21.08 & 3 & 7.03 & 11.37 & 0.199 \\
$\begin{array}{l}\text { Pure error } \\
\text { Correction for }\end{array}$ & 2.47 & 4 & 0.62 & & \\
total sum & 98.71 & 16 & & & \\
\multicolumn{5}{l}{} \\
& $\mathbf{R}_{\text {RSM: } \mathbf{8 4 . 5 4 \%}}$ & $\mathbf{R}_{\text {ANN }}^{\mathbf{2}} \mathbf{8 7 . 1 2 \%}$ & \\
\hline
\end{tabular}




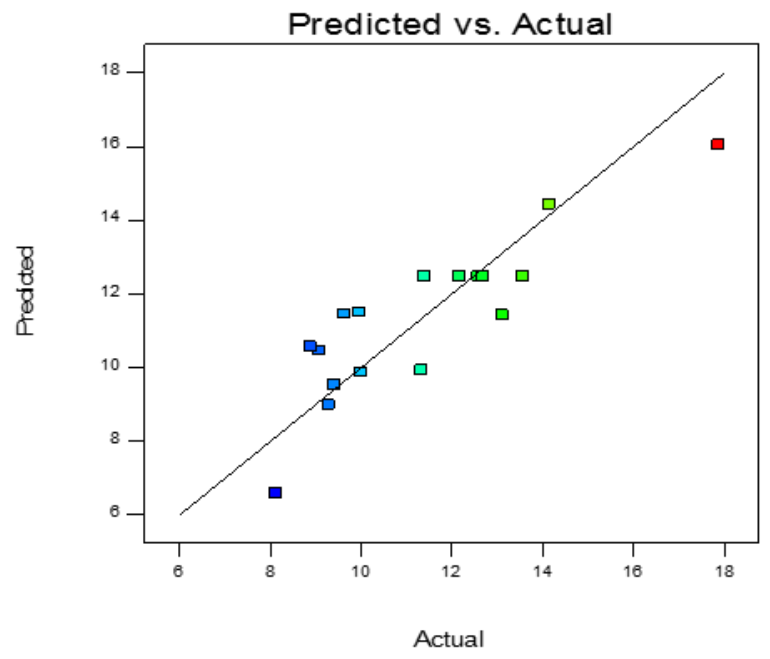

RSM

Figure 1: Actual yield Vs. Predicted values.

the relationship between the response and the experimental levels of each variable on the one side, and the type of interactions between the test variables, on the other, which allows for deducing the optimum conditions. The interaction effects of solvent volume (SV), sample weight (SW) and extraction time (ET) on the oil yield were studied using the contour plots and 3D surface plots of RSM (Figure 2 (a-d)). From the plots, it was observed that the oil yield increased with decreases in ET and SV while keeping SW constant at zero level. The curvature nature of the surface plots in Figures 2 (b-e) depict mutual interactions between ET and SV

Table 5: Regression Coefficients and Significance of Response Surface Quadratic

\begin{tabular}{lllllll}
\hline Factor & $\begin{array}{l}\text { Coefficient } \\
\text { estimate }\end{array}$ & df & $\begin{array}{l}\text { Standard } \\
\text { error }\end{array}$ & $\begin{array}{l}\text { 95\% } \\
\text { CI } \\
\text { Low }\end{array}$ & $\begin{array}{l}\text { 95\% } \\
\text { CI } \\
\text { High }\end{array}$ & VIF \\
\hline Intercept & 12.48 & 1 & 0.82 & 10.54 & 14.42 & \\
$\mathrm{X}_{1}$ & -1.01 & 1 & 0.65 & -2.55 & 0.52 & 1.00 \\
$\mathrm{X}_{2}$ & 1.28 & 1 & 0.65 & -0.25 & 2.81 & 1.00 \\
$\mathrm{X}_{3}$ & -1.44 & 1 & 0.65 & -2.98 & 0.090 & 1.00 \\
$\mathrm{X}_{1} \mathrm{X}_{2}$ & -1.78 & 1 & 0.92 & -3.95 & 0.39 & 1.00 \\
$\mathrm{X}_{1} \mathrm{X}_{3}$ & -0.98 & 1 & 0.92 & -3.15 & 1.19 & 1.00 \\
$\mathrm{X}_{2} \mathrm{X}_{3}$ & -1.00 & 1 & 0.92 & -3.17 & 1.17 & 1.00 \\
$\mathrm{X}_{1}{ }^{2}$ & -0.59 & 1 & 0.89 & -2.71 & 1.52 & 1.01 \\
$\mathrm{X}_{2}{ }^{2}$ & 0.095 & 1 & 0.89 & -2.02 & 2.21 & 1.01 \\
$\mathrm{X}_{3}{ }^{2}$ & -1.86 & 1 & 0.89 & -3.98 & 0.25 & 1.01 \\
\hline
\end{tabular}

Figures 2 (b-e) depict mutual interactions between ET and SV on oil yield. It was observed that an increased in SW and SV favoured the high yield of the oil, while low SV and low SW reduced the oil yield. Figures 2 (c-f) showed the interaction between the SW and ET on the yield of oil. It was also observed that the high SW with low ET produced the highest oil yield. Further increase in ET reduced the yield of the oil.
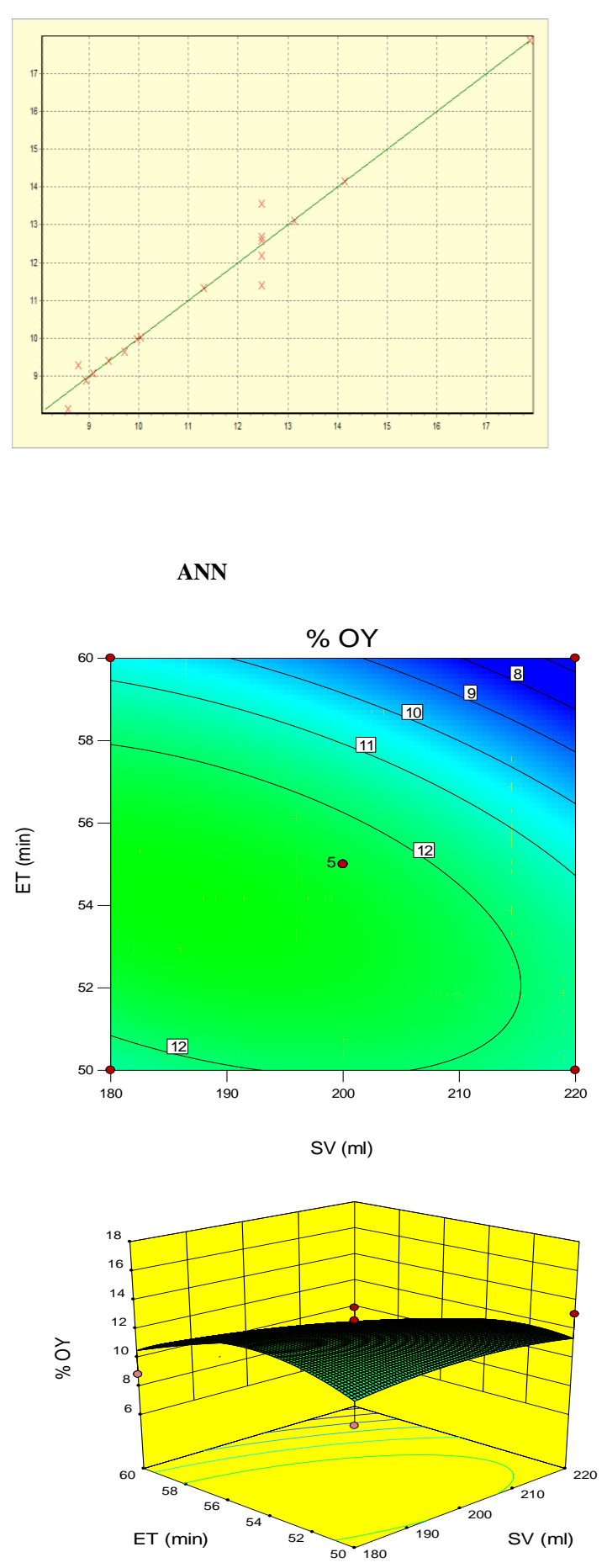

Fig. 2(a)

The RSM and ANN plots of contours and the 3 D's showed that the highest oil yield was obtained at high SW, low ET and low SV (Figures 2(b-e \& c-f)). 

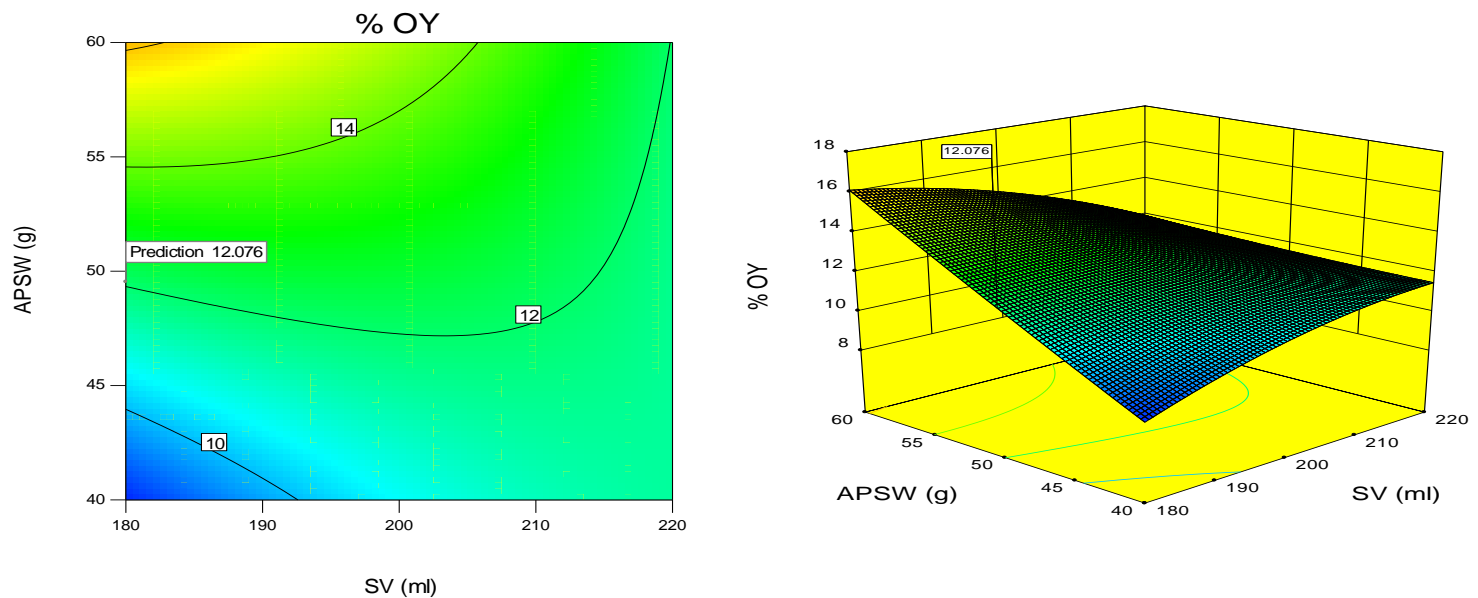

Fig. 2(b)
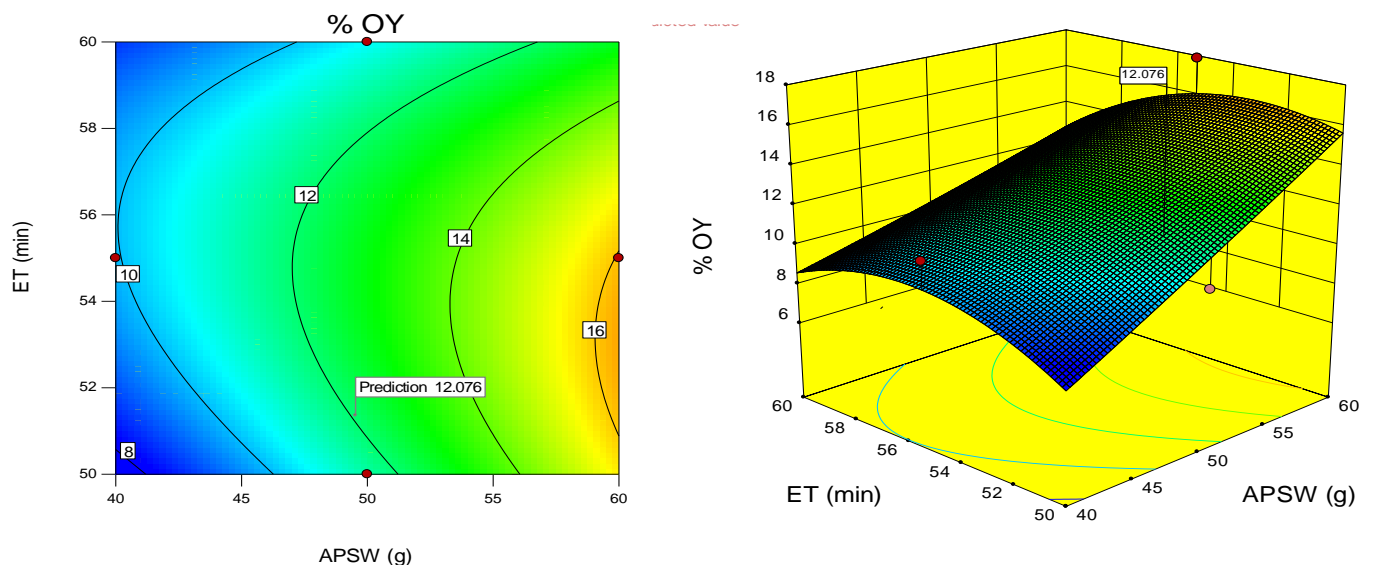

Fig. 2(c)
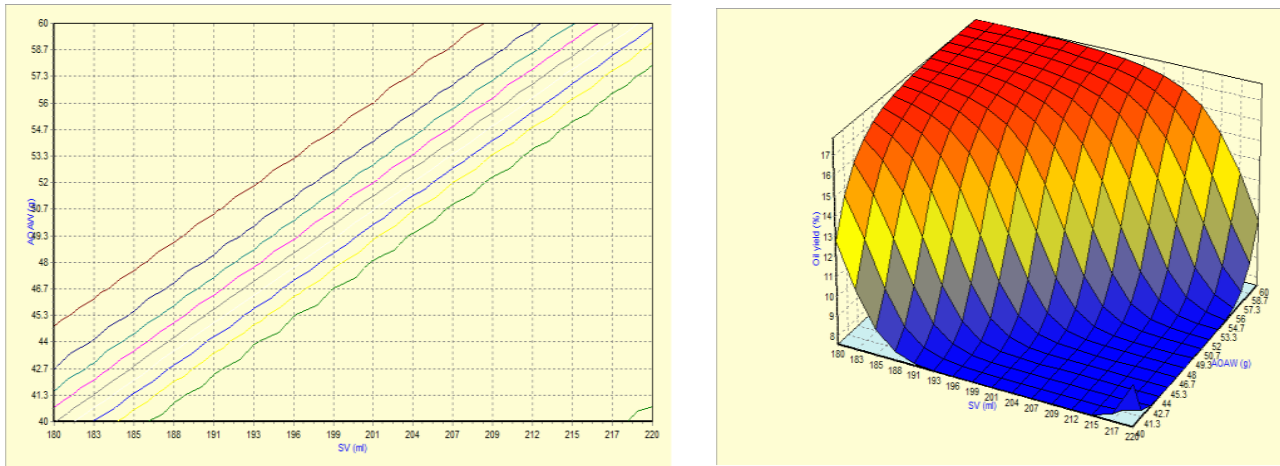

Fig. 2(d)
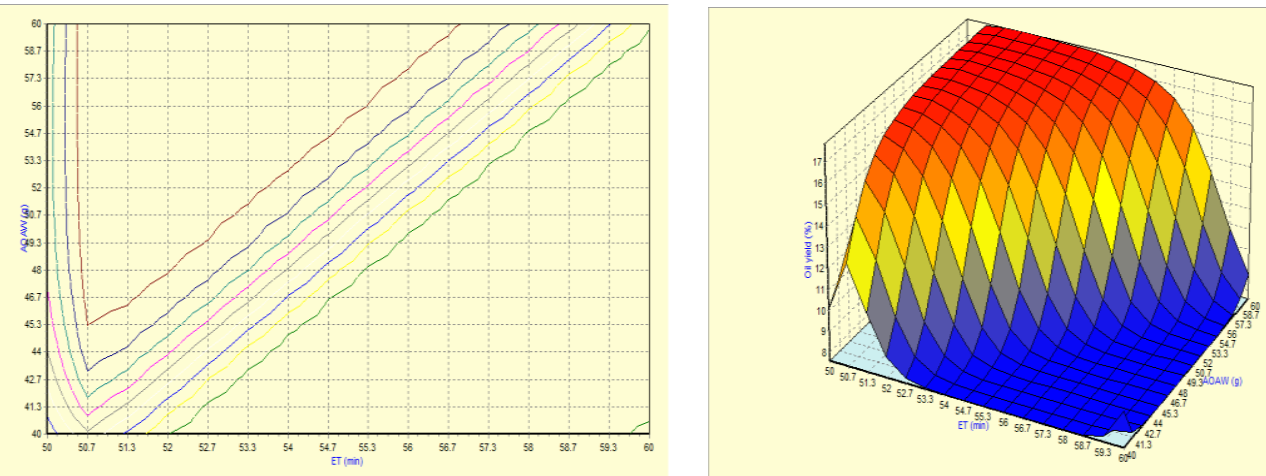

Fig. 2(e) 

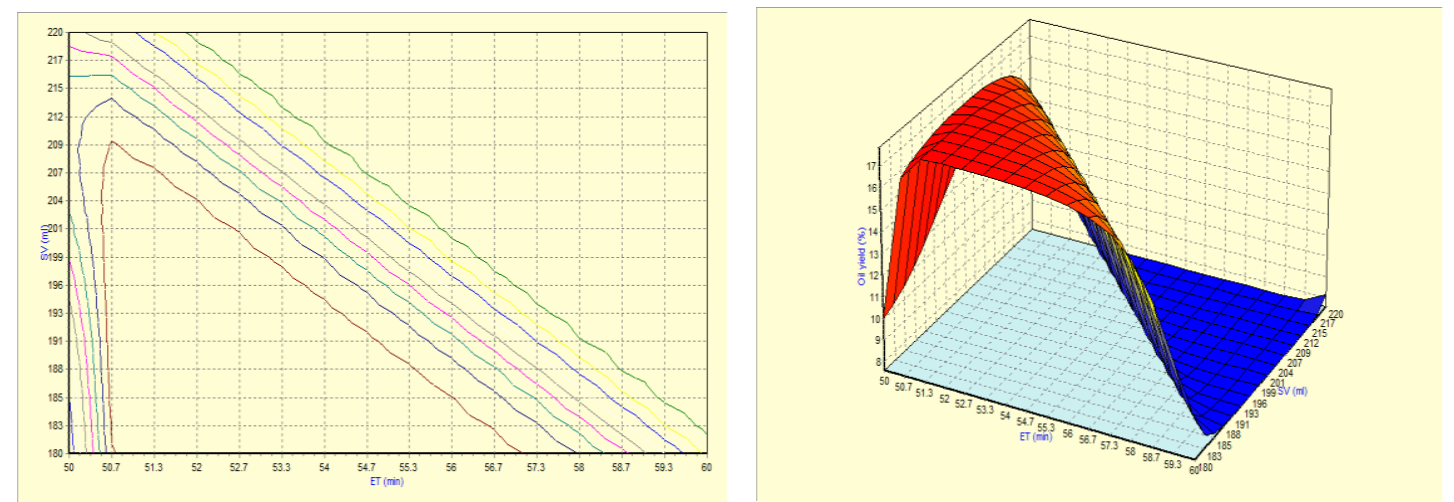

Fig. 2(f)

Figure 2(a-f): Contours and 3- Dimensional plots by RSM and ANN.

\section{E. Physiochemical Properties of African Pear Oil (APO)}

Table 6 showed the results of the physicochemical properties of the extracted oil obtained using (AOAC, 1997) standard methods. The oil obtained was liquid, brownish in colour with the moisture content of $0.04549 \%$ and specific gravity of 0.9217 . The high acid value of 27.072 corresponding to high FFA of 13.036 obtained in this study indicated the good resistance of the oil to hydrolysis. Peroxide value measures the content of hydroperoxides in the oil (Mcginely, 1991) and its high value (37.60 meq. $\mathrm{O}_{2} / \mathrm{kg}$ ) indicates high resistance to oxidation.

High saponification value of $129.03 \mathrm{mg} \mathrm{KOH} / \mathrm{g}$ with a high iodine value of $78.09 \mathrm{gI}_{2} / 100$ g indicated a low concentration of triglycerides and the oil contained a substantial level of unsaturation. The high heating value of $42.968 \mathrm{MJ} / \mathrm{kg}$ takes into account the latent heat of vaporization of water in the combustion products. Fuel properties such as Cetane number, a measure of the fuel's ignition delay and combustion quality, and its fuel standard is a minimum of 40 (Meher et al., 2006; Ramos et al., 2008). The high value of 71.03 obtained in this study showed the oil has high fuel potential.

\begin{tabular}{ll} 
Table 6: Physiochemical Properties of oil. & \\
\hline Parameters & Values \\
\hline Physical properties & \\
\hline Absorbance @ $660^{\circ} \mathrm{C}$ & 2.032 \\
Moisture content $(\%)$ & 0.04549 \\
Specific gravity & 0.9217 \\
Mean Molecular mass & 434.008 \\
Viscosity @ $34.2^{\circ} \mathrm{C}\left(\mathrm{N} . \mathrm{s} / \mathrm{m}^{2}\right)$ & 1.282 \\
Chemical Properties & \\
\hline Free Fatty Acid & 13.036 \\
Acid Value $(\mathrm{mg} \mathrm{KOH} / \mathrm{g}$ oil) & 27.072 \\
Saponification Value $(\mathrm{mg} \mathrm{KOH} / \mathrm{g}$ oil) & 129.03 \\
Iodine Value $(\mathrm{g} \mathrm{I} / 100 \mathrm{~g}$ oil) & 78.09 \\
Peroxide Value $\left(\mathrm{meq} \mathrm{O}_{2} / \mathrm{kg} \mathrm{oil)}\right.$ & 37.60 \\
Higher Heating Value $(\mathrm{MJ} / \mathrm{kg})$ & 42.968 \\
Other Properties & \\
\hline Cetane number & 71.0299 \\
\hline
\end{tabular}

Dacryodes edulis seeds oil extraction showed the highest oil yield of $17.878 \%(\mathrm{w} / \mathrm{w}$ ) at solvent volume of $200 \mathrm{ml}$, sample weight of $50 \mathrm{~g}$ and extraction time of $55 \mathrm{~min}$, respectively. However, response surface methodology predicted an oil yield of $17.826 \%(\mathrm{w} / \mathrm{w})$, while the artificial neural network predicted $17.875 \%(\mathrm{w} / \mathrm{w})$ at the same variables condition. The predicted values were validated in triplicate, and an average of $17.46 \%(\mathrm{w} / \mathrm{w})$ and $17.72 \%$ (w/w) were obtained for RSM and ANN, respectively. The predicted values obtained were well within the range predicted. The coefficient of determination, which determines the model accuracy, was obtained to be 0.8454 for RSM and 0.8712 for ANN. Physicochemical analysis of the oil showed the oil is highly unsaturated with high saponification value and high iodine value.

\section{REFERENCES}

Adeniyi, T.; S. Densley and H. R. Lemu. (2014). Deforestation: FCT sits on a tighttrope. Daily Trust, City news. Accessed on March 28, 2017.

Australian Academy of Science AAS, (2018). The science of climate change. Available online at: https://www.science.org.au/learning/general-

audience/science-booklets-0/science-climate-change/2-howhas-climate-changed. Accessed on March 14, 2018.

Cyblug (2016). Climate and Weather. Abuja City, Nigeria. Available online at: www.abujacity.com/abuja _and_beyond/climate-and-weather.html. Accessed on March 28, 2017.

Dongjie, G., Hidetoshi F., Weijun G., and Kazuyuki W. (2008). Land use change of Kitakyushu based on landscape ecology and Markov model. J Geogr Sci. 18:455468.

Decision Lens. (2015). Decision Lens. Retrieved from http://www.decisionlens.com. Assessed on March 12, 2018.

Eletta, O. A. A.; S. I. Mustapha; O. A. Ajayi and A. T. Ahmed. (2018). Optimization of Dye Removal from Textile Wastewater using Activated Carbon from Sawdust. Nigerian Journal of Technological Development. 15 (1): 26-32. 
Food and Agriculture Organisation (FAO): Water Reports (2010). The wealth of waste: The economics of wasteater use in agriculture. Available online at: http://apps.fao.org. Assessed on April 8, 2017.

Gould, J.E., (1992). Rainwater Catchment Systems for Household Water Supply, Environmental Sanitation Reviews, No. 32, ENSIC, Asian Institute of Technology, Bangkok.

Gould, J. and Nissen-Peterson, E. (1999). Rainwater Catchment Systems for Domestic Supply: Design, Construction and Implementation. Intermediate Technology Publications, London, 335: 1999.

Huang, W.; Q. Luan; H. Liu; X. Mu and M. Bai. (2008). Monitoring urban expansion in Beijing, China by multi temporal TM and spot images. IEEE Proc, IGARSS. 4:695-698.

Intergovernmental Panel on Climate Change (IPCC). (2007). Assessment report; Climate Change 2007 Summary for policymakers. Valencia, Spain.

Jianping, L. I.; G. Feng and Z. Bai. (2005). RS-andGIS-supported forecast of grassland degradation in southwest Songnen plain by Markov model. Geo-spatial Inf Sci. 8:104106.

Jonathan, R. B. F.; A. A. Eileen; P. J. DennedyFrank; K. Timm and M. B. Timothy. (2017). Impact of satellite imagery spatial resolution on land use classification accuracy and modeled water quality. Available online at: https://doi.org/10.1002/rse2.61. Published 20 August 2017

Kahinda, J. M.; E.S. B. Lillie; A. E. Taigbenu; M. Taute and R. J. Boroto. (2008). Developing suitability maps for rainwater harvesting in South Africa. Physics and Chemistry of the Earth 33: 788-799.

Kisakye, V.; M. Akurut and B. V. Bruggen. (2018). Effects of climate change on reliability of rainwater harvesting systems for Kabarole District, Uganda. Available online at: www,mdpi.come/journal/water.

Kogbe, C. A. (1976). Paleogeographic History of Nigeria from Albian Times. Elizabeth Publishers, Lagos, 237-252.

Logsdon, M. G.; V. F. Westerlund and J. E. Bell. (1996). Probability mapping of land use change: a GIS interface for visualizing transition probability. Computer Environ Urban Syst. 20:389-398.

Mahmoud, S. H., and Alazba, A. A. (2014). The potential of in-situ rainwater harvesting in arid regions: developing a methodology to identify suitable areas using GIS-based decision support system Saudi Society for Geosciences, 1-13.
Maimbo, M.; K. Elizabeth; M. Bancy; O. Alex; D. B. Tanguy; N. Meshack and V. Oduor. (2005). Mapping the potentials of rainwater harvesting in Africa. GWP-AP Series of ICRAF publications, Nairobi.

Mbilinyi, B. P.; S. D. Tumbo; H. F. Mahoo; E. M. Senkondo and N. Hatibu. (2005). Indigenous Knowledge as Decision Support Tool in Rainwater Harvesting. Physics and Chemistry of the Earth. 30: 792-798.

Mongaby.com (2018). Nigeria Environmental profile. Available online at:

https://rainforests.mongaby.com/deforestation/achive/Nigeria. htm. Assessed on April 12, 2018.

Mohamed, E.; H. Arouri; A. B. Youssef; C. Nguyenviet; M. El and H. Arouri. (2014). Effects of urbanization on economic growth and human capital formation in Africa. PGDA Working Paper No. 119: 1-23.

Muller, R. M., and Middleton, J. (1994). A Markov model of land-use change dynamics in the Niagara region, Ontario, Canada. Landscape Ecol. 9:151-157.

Odot Hydraulic Manual; available online at: http://www.oregon.gov/ODOT/GeoEnvironmental Docs/HydraulicsManual/Hydraulics-07-F.pdf.

Pacey, A., and Cullis, A. (1989). Rainwater Harvesting: The Collection of Rainfall and Runoff in Rural Areas, WBC Print Ltd., London.

Pandey, D. N., Gupta, A. K., and Anderson, D. M., (2003). Rainwater harvesting as an adaptation to climate change. Current science, 85(1): 46-59.

Rainwater Harvesting. (2006). Centre for Science and Environment.

http://www.rainwaterharvesting.org/methods/methods.htm. Accessed on April 18, 2018.

Rutherford, R. (2000). Water harvesting: An overview. Available online at: www.protos.ngo

Saaty, T. L. (1980). The analytic hierarchy process. McGraw-Hill, New York.

Stratfor Global Intelligence, (2014). Water Scarcity; Examining Impacts around the World. STRATFOR Global Intelligence. Accessed on Februrary 8, 2018.

Udezo, N. V. (2017). Flood Vulnerability Assessment and Management for Kaduna Metropolis, Kaduna State Nigeria. M.Sc. Thesis, Department of Environmental Management, Pan African University Institute of Life and Earth Sciences, University of Ibadan, Ibadan, Nigeria.

Zhang, R.; L. Gao; W. Fan; C. Tang; H. Yuan and S. Ma. (2011). Using Markov chains to analyze changes in wetland trends in arid Yinchuan plain, China. Math Compute Modell. 54:924-930. 